\title{
The main roles of bankruptcy administrator in Albanian Bankruptcy Law
}

\author{
Erjola Aliaj, Msc, PhD candidate \\ European University of Tirana \\ E-mail:aerjola@gmail.com
}

\begin{abstract}
The bankruptcy procedure in Albania is governed by Bankruptcy Law No.8901 dated 23 May 2002, as amended. This law establishes non-discriminatory and mandatory rules for the repayment of the obligations by debtors in a bankruptcy procedure and ensures an adequate, reliable and effective mechanism for the reorganization or liquidation of a commercial company that is facing financial difficulties. Moreover, this law intervenes not only in the procedural rights of creditors towards insolvent debtors, but also in the material contractual and property rights of the persons, who had a legal relation with the insolvent debtor before and or/after the bankruptcy procedure has started. The administrator plays a fundamental role in the bankruptcy procedure. The latter is given heuristic, determined, regulatory and managerial powers in Albanian Bankruptcy Law. This paper provides an analysis of the main roles of bankruptcy administrator in Albanian Bankruptcy Law, such as control and distribution of bankruptcy estate, use or disposal of property, role in executor contracts, and contest of transactions.etc.
\end{abstract}

Keywords: Albanian Bankruptcy law, role, bankruptcy administrator

\section{The roles of a bankruptcy administrator.}

The administrator plays a central, multifaceted role in the bankruptcy procedure (Galgano, 1992). Despite the administrator is given investigatory, adjudicative, administrative and management powers, the most important decisions made by the administrator are subject to supervision by the creditors' committee or meeting of the creditors (Katro,2004). For example, the decision to keep or close/liquidate a business enterprise in whole or in part or to prepare a bankruptcy plan is made by the meeting of creditors or the creditors' committee based on a report prepared by the administrator. ${ }^{1}$. Also, for undertaking important actions, that may affect the bankruptcy procedure, such as, sale of activity, company, enter into loan contract and file a lawsuit, the consent of the meeting of creditors or the creditors' committee is required. ${ }^{2}$ Furthermore, the consent of the creditors' committee is required even in case of sale of the company to a person, who owns $20 \%$ of the capital, who is in close relations with the debtor and is a creditor with special repayment rights. ${ }^{3}$

\subsection{The control of Bankruptcy Estate}

After the bankruptcy procedure is opened, according to article 116 of Bankruptcy Law, the administrator immediately takes possession and management of the bankruptcy estate (Torreman, Tegu \& Shehi, 2005). The administrator may enforce the recovery of the debtor's property by means of an executive title. ${ }^{4}$ The administrator shall prepare a record of all assets that constitutes the bankruptcy estate in collaboration with the debtor (Cuming, Baranes, 2013). In this record, should be defined the value of each asset. In case the value of the asset depends on whether the debtor activity will continue or will be closed, the administrator should present an alternative value. ${ }^{5}$ The administrator shall deposit the current record of assets with the Bankruptcy Court. ${ }^{6}$ The bankruptcy administrator compiles a list of all creditors of the debtor, who have become known by the books of the debtor, by notification of the debtor, upon their request or in any other way (Torreman, Tegu \& Shehi, 2005). The list must show the state that enables mutual compensation of claims and the amount of obligations toward the bankruptcy estate in case of a rapid sale of the debtor's property. ${ }^{7}$ As a result of article 67 , the

\footnotetext{
${ }^{1}$ Article 124 -125 of Bankruptcy Law no.8901 dated 23 May 2002, as amended.

2 lbid. article 128

${ }^{3} \mathrm{lbid}$. article 130

${ }^{4}$ Ibid. article 116 point 2

5 lbid. article 119

${ }^{6}$ lbid. article 122

7 lbid. article 120
} 
debtor's right to manage and dispose of the assets of the bankruptcy estate vests in the administrator (Cuming, Baranes, 2013).Technically, the administrator does not become the owner of the property. However, according to article 68, the debtor loses the power to deal with the property and any attempt by the debtor to do so is legally invalid (Katro, 2004).The debtor does, however, have a limited power to give a discharge of an obligation owing to the estate when the performing party provides performance to the debtor after opening of the proceeding and without being aware of the fact that the proceedings have started. If the proceeding has not been published, the performing party is presumed to be unaware of the proceeding. ${ }^{1}$ All civil claims, where the debtor is a party, as stated in article 71 , shall be suspended upon opening of bankruptcy proceedings (Torreman, Tegu \& Shehi, 2005). A feature of the control over the estate property vested in the administrator is the power to restart in favor of the estate any action affecting the property the debtor had at the date the proceeding was opened (Galgano, 1992). Also, the administrator may continue actions against the debtor relating to claims on:

a) separation of an asset from the bankruptcy estate;

b) special repayment; and

c) the obligation toward the bankruptcy estate. ${ }^{2}$

Referring to article 77 , the bankruptcy administrator is the only person who, during the bankruptcy proceedings, can claim the right to compensation for damages of bankruptcy creditors incurred before or after the opening of bankruptcy proceedings, due to the decrease of the bankruptcy estate (Katro, 2004). The meeting of creditors is the authority, which decides whether the debtor and his family should be granted from the bankruptcy estate of an amount for living (Torreman, Tegu \& Shehi, 2005). Also, the administrator may grant interim maintenance to the debtor and his/her family, until a decision shall be taken by the meeting of creditors. ${ }^{3}$

\subsection{Fulfillment of legal actions}

\subsubsection{Administrator's Right under Contract not Performed by both Parties}

There are some important circumstances in which the invocation of a bankruptcy proceeding can have a very significant effect on the rights of persons who have entered into transactions with or who have received property from the debtor before a bankruptcy proceeding has been opened or a request to open bankruptcy proceedings has been made (Cuming, Baranes, 2013). The administrator is given significant options with respect to such contracts (Galgano, 1992). Article 86 provides that when at the date of opening of the proceedings a contract between the debtor and another person has not been performed by either party, the bankruptcy administrator may opt to perform the contract instead of the debtor and claim by the other party damages or fulfillment of the contractual obligations (Torreman, Tegu \& Shehi, 2005). If the administrator does not accept to execute the contract, the other party has the right to claim the non execution of the contract only as a bankruptcy creditor. In other words, the Bankruptcy Law precludes an action for specific performance of the contract brought by the other party (Cuming, Baranes, 2013).

\subsubsection{Limitation on Administrator Right under Contract not Performed by both Parties}

Bankruptcy law provides limitation on administrator rights under specific contracts such as forwarding and financial future contracts $^{4}$ and contracts for the sale of movables by the bankruptcy debtor providing for the reservation of ownership ${ }^{5}$.

Article 87 contains special rules applicable to forwarding and financial futures contracts (Katro, 2004). According to article 87 , if it is agreed that the goods shall be delivered on a certain date or within a certain period of time and if this period ends on or after the bankruptcy proceedings are open, the other party cannot require the execution of the contract, but can have claims about the no execution of the obligations, only in the quality of bankruptcy creditor (Torreman, Tegu \& Shehi, 2005).

\footnotetext{
${ }^{1} \mathrm{lbid}$. article 69

$2 \mathrm{lbid}$. article 72 and 73 point 1

3 lbid. article 84

${ }^{4}$ lbid. article 87

5 lbid. article 89
} 
Referring to article 88 , if contractual services that constitute obligations to contractual parties are periodic, and if the other party has fulfilled part of the service at the time the bankruptcy proceedings are open, this party is called bankruptcy creditor, even if the administrator pretends the execution of non performed services (Cuming, Baranes, 2013). According to article 89 , if the debtor has sold a movable property with the reservation of ownership before the bankruptcy proceeding was open and the buyer has taken possession of the property, the latter may pretend the execution of the sale contract (Torreman, Tegu \& Shehi, 2005).

\subsection{Disagreement of debtor's actions}

The most significant effect of bankruptcy on the operation of non-bankruptcy law as it applies to contractual or property rights acquired by other persons from the debtor is the power given to the administrator to have declared invalid a transaction that in a non-bankruptcy context may be valid (Galgano, 1992). Under articles 100-105, the bankruptcy administrator may treat as invalid transactions that "disadvantage bankruptcy creditors" occurring within specified periods prior to opening the bankruptcy proceedings or after a request to open a bankruptcy proceeding (Cuming, Baranes, 2013). This power can be exercised in several contexts:

- when the debtor has given security or payment of debts to bankruptcy creditors within 90 days prior to the opening of the proceeds or after the opening of the proceeding and at a time when the debtor was illiquid. ${ }^{1} \mathrm{~A}$ person with a close relationship with the debtor, as defined in article 107 is presumed to know of the illiquidity or the bankruptcy proceeding.

- when the debtor has entered into transactions providing "incongruent coverage" of a debt made within 3 months prior to invocation of bankruptcy proceedings including a time when the debtor is not illiquid and the other party to the transaction is unaware of the effect on creditors or as a result of gross negligence was unaware of the illiquidity of the debtor or the request to open the proceeding. ${ }^{2}$

- when the debtor has entered into transactions that are immediately disadvantaging the bankruptcy creditors

- when the debtor has entered into transactions with the intention to disadvantage the creditors occurring within 10 years before the date of the request to open the proceeding if the other party was aware of this intention, the debtor's illiquidity or the effect of the transaction on creditors. ${ }^{3}$

- when the debtor has entered into an onerous contract with a person having a close relationship with the debtor, as defined in article 107, who is aware of the debtor's intention to disadvantage his/her creditors, occurring within 2 years before the request to open the proceeding. ${ }^{4}$

- when the debtor has made a gift of property (other than a casual gift of a minor nature) within 4 years before the request to open a proceeding. ${ }^{5}$

- when a transaction is performed by execution pursuant to an executive title (Cuming, Baranes, 2013).

\subsection{Disposal and use of assets}

According to article 133 , the administrator may dispose with no restriction any asset that is subject to the special repayment right (Torreman, Tegu \& Shehi, 2005). Also, he may dispose differently a claim that the debtor has assigned to a creditor as security (Katro, 2004). There is a limitation to such right of the administrator, in case the value of the collateral is smaller than or equal to the loan amount alleged by the secured creditor or expenses amount for its execution, taken together (Cuming, Baranes, 2013).

\footnotetext{
1 Ibid article 101-102

2 lbid. article 103

3 lbid. article 104

${ }^{4}$ Ibid. article 104 point 2

${ }^{5}$ lbid article 105
} 
In order to exercise such a right, the administrator must meet some procedural requirements such as the notification of the creditor having the right of special repayment in relation to the condition of the property, to the sale of the property, and to protect the creditor's interest in case of an overdue sale (Torreman, Tegu \& Shehi, 2005).

According to article 139, the bankruptcy administrator may decide to use for the bankruptcy estate an asset, over which has the right of disposal, when the loss of value caused by the use shall be compensated with payments to creditors with the opening of bankruptcy proceedings (Katro, 2004). This compensatory payment obligation exists only to the extent to which the loss of value from the use violates the right of the creditor with special repayment (Torreman, Tegu \& Shehi, 2005).

The administrator may also unit, process and mixes the asset with other properties so long as the security position of the secured creditor is not thereby impaired (Cuming, Baranes, 2013).

\subsection{The assessment of creditors' claims}

According to article 141-142, the bankruptcy creditors must submit their claims in writing to the bankruptcy administrator (Torreman, Tegu \& Shehi, 2005). The latter records all claims with data and files them in the court. (Galgano, 1992). The administrator plays only a supplementary role in assessing the validity of these claims (Katro, 2004). The decision whether a claim has or has not been verified is made by the meeting of creditors in a verification meeting ${ }^{1}$ or by the Bankruptcy Court ${ }^{2}$. However, the administrator has the obligation to assess the claims and to indicate which should be accepted or denied (Cuming, Baranes, 2013).

\subsection{Distribution of the Estate.}

The Administrator is responsible for the distribution of the bankruptcy estate (Torreman, Tegu \& Shehi, 2005). The initiation of a distribution must take place only after the general verification meeting of the creditor ${ }^{3}$. However, before making any distribution a list of claims must be published at the Bankruptcy Court with details about the distribution and which parties benefit from it ${ }^{4}$. The distribution list must address the following critical areas:

- The order of priorities as provided in Article 605 of Albanian Civil Code; 5

- Costs of the proceeding and administrative debts that have priority over the claims of bankruptcy creditors; ${ }^{6}$

- Claims of secured creditors; ${ }^{7}$

- Amount retained for not determined or conditional claims (Cuming, Baranes, 2013).

\section{Other roles of the Bankruptcy Administrator}

According to article 160 of Bankruptcy Law, the administrator's accounts must be presented by the administrator to a meeting of creditors convened by the Bankruptcy Court (Katro, 2004). The administrator, as stated in article 61-62, is entitled to request that the Bankruptcy Court convene a meeting of creditors and is entitled to attend and participate in such a meeting (Torreman, Tegu \& Shehi, 2005). The Bankruptcy Court may decide to reject the request. If the Bankruptcy Court rejects the request, the administrator has the right to appeal this decision in accordance with the Code of Civil Procedure (Cuming, Baranes, 2013). Referring to article 145-146 and article 152, the administrator has also role in assessing the validity of creditors' claims. The administrator may deny a filed claim at the verification meeting (Katro, 2004). The effect of this denial is that the creditor whose claim in denied must bring an action in court to establish the claim, unless the claim is

\footnotetext{
$1 \mathrm{lbid}$. article 143

2 lbid. articles 147-148

${ }^{3}$ Ibid article 150

4 lbid. article 151

5 lbid. article 150 point 3

${ }^{6} \mathrm{lbid}$. articles 37-38

$7 \mathrm{lbid}$. articles 35,41 and 153
} 
based on an executable deed or final judgment, in which case the administrator must bring action and have the claim assessed (Torreman, Tegu \& Shehi, 2005). The administrator, as defined in article 66, may be required to give reports to the meeting of creditors with respect to progress of the proceedings and the management of the bankruptcy estate. (Cuming, Baranes, 2013). An important aspect of the duties of the administrator involves handling of labor contracts (Galgano, 1992). The administrator has the right to terminate labor contracts. However, this must be done in accordance with the provisions of Albanian Labor Code in order to minimize the volume of claims of the insolvent's employees (Torreman, Tegu \& Shehi, 2005).

\section{Conclusions}

The Bankruptcy Law plays an important role in all of the countries with a highly developed economy. The Bankruptcy Law is an evident adaptation of German legislation which in many respects does not fit with the needs of a developing economy. The role of the administrator in the administration of the bankruptcy estate is significant. The law does not provide clearly specific criteria for the appointment of a bankruptcy administrator, except for the requirement that the administrator should have a background in economics. The roles of the administrator must be carried out by trained, capable and competent persons. The banruptcy administrator must duly and properly perform, during the whole procedure until it is closed, the duties stated in law. The analysis of the main roles of the administrator shows that the legislator has regulated, in detail these aspects of bankruptcy procedure. The main roles of bankruptcy administrator in Albanian Bankruptcy Law are control and distribution of bankruptcy estate, use or disposal of property, role in executory contracts, and contest of transactions etc. His performance is supervised by the Bankruptcy Court and by the Creditor's Meeting and the Creditor's Committee. Currently, there are no many cases judged in regards to the non fulfillment of his duties by the bankruptcy administrator.

\section{References}

\section{Legislation}

[1] Bankruptcy Law no.8901 dated 23 May 2002, amended.

[2] Decision of the Council of Ministers No. $125 \mathrm{dt} .06 .02 .2013$ "On approval of the code of ethics for the bankruptcy administrators"

[3] Instruction No.22 dt.29/07/2008 "On assigning the interim bankruptcy administrators"

\section{Monographies}

[1] Cuming C.C. R., Baranes Y., (2013) Manual on the Albanian Bankruptcy Law. Maluka Publishing House.

[2] Torremans, P., Tegu, F., Shehi, A. (2005). Bankruptcy in comparative aspect, Tirana, Kristalina -KH Publishing House

[3] Galgano, F. (1992). Commercial law (Seventh edition), Rome

[4] Katro, K. (2004). Bankruptcy Law 